\title{
High levels of congenital transmission of Toxoplasma gondii in longitudinal and cross-sectional studies on sheep farms provides evidence of vertical transmission in ovine hosts
}

\author{
R. H. WILLIAMS ${ }^{1}$, E. K. MORLEY ${ }^{1}$, J. M. HUGHES ${ }^{1}$, P. DUNCANSON ${ }^{1}$, R. S. TERRY ${ }^{2}$, \\ J. E. SMITH ${ }^{2}$ and G. HIDE ${ }^{1 *}$ \\ ${ }^{1}$ Centre for Parasitology, Molecular Epidemiology and Ecology, Bioscience Research Institute, School of Environment \\ and Life Sciences, University of Salford, Salford M5 4WT, UK \\ ${ }^{2}$ School of Biology, University of Leeds, Leeds LS2 9TF, UK
}

(Received 2 March 2004; revised 11 August 2004; accepted 17 August 2004)

\section{SUMMARY}

Recent research suggests that vertical transmission may play an important role in sustaining Toxoplasma gondii infection in some species. We report here that congenital transmission occurs at consistently high levels in pedigree Charollais and outbred sheep flocks sampled over a 3-year period. Overall rates of transmission per pregnancy determined by PCR based diagnosis, were consistent over time in a commercial sheep flock $(69 \%)$ and in sympatric (60\%) and allopatric (41\%) populations of Charollais sheep. The result of this was that $53.7 \%$ of lambs were acquiring an infection prior to birth: $46 \cdot 4 \%$ of live lambs and $90.0 \%$ of dead lambs (in agreement with the association made between T. gondii and abortion). No significant differences were observed between lamb sexes. Although we cannot distinguish between congenital transmission occurring due to primary infection at pregnancy or reactivation of chronic infection during pregnancy, our observations of consistently high levels of congenital transmission over successive lambings favour the latter.

Key words: Toxoplasma gondii, congenital transmission, ovine, abortion.

\section{INTRODUCTION}

The protozoan parasite Toxoplasma gondii is common to most warm-blooded organisms (Dubey \& Beattie, 1988; Tenter, Heckeroth \& Weiss, 2000). It is normally apathogenic and serious disease is restricted to those with a weakened or immature immune system as is the case with a developing foetus. Sheep are particularly susceptible and primary infection leads to congenital disease or abortion (Beverley $\&$ Watson, 1971 ; Buxton, 1990). Serological assessment suggests that $25-36 \%$ of sheep in the British Isles are infected (Leguia \& Herbert, 1979; Samad \& Clarkson, 1994) and the disease accounts for one third of all diagnosed ovine abortions (SAC Veterinary Science Division, 1999). It has long been held that the major route of transmission was via oocysts released in the faeces of the felid definitive host following sexual recombination (Hutchison, 1965) and this has been proposed as the main transmission route in sheep. In carnivores and omnivores, transmission of asexual bradyzoite stages by carnivory is also important and recent reports suggested that this favoured transmission route has led to the expansion and clonal population structure of the parasite (Su et al. 2003). Although

* Corresponding author: School of Environment and Life Sciences, Peel Building, University of Salford, Salford M5 4WT, UK. Tel: +0161295 3371. Fax: +0161 295 5015. E-mail: g.hide@salford.ac.uk transplacental transmission of the parasite is demonstrated in many species, it is usually considered in terms of disease rather than as a potential route of transmission.

Beverley was the first to suggest that serial vertical transmission might sustain the parasite (Beverley, 1959) and that this might be important in maintaining the parasite in some populations, however this has been a contentious issue (Johnson, 1997). Supportive evidence of vertical transmission over a single generation has been obtained in populations of experimentally infected mice (Apodemus sylvaticus and Mus domesticus) (Owen \& Trees, 1998) and in natural populations of domestic mouse ( $M$. domesticus) (Marshall et al. 2004). Experimentally infected rats exhibit high rates of parasite transmission to offspring when infected during pregnancy (Dubey \& Shen, 1991; Dubey et al. 1997) although rates were found to differ depending on parasite strain, host infection route and parasite stage (Zenner et al.1993). Furthermore, the situation in rats was different from that observed in mice and hamsters where $T$. gondiiinfected dams could produce several infected litters without re-infection (Beverley, 1959; RoeverBonnet, 1969). More recently high rates of congenital transmission have been reported in epidemiological investigations in sheep (Duncanson et al. 2001). The mechanism by which congenital transmission in these various species is achieved is less clear. Two possible scenarios can be envisaged: firstly, primary 
exposure of the female during pregnancy followed by transmission to the foetus during pregnancy or secondly, reactivation of chronic infection in the female during pregnancy. There is currently contention as to the importance and relevance of congenital transmission in toxoplasmosis.

Past estimates of Toxoplasma infection in sheep suggest a median of $30 \%$ infection amongst ewe populations by serology (Blewett, 1983; Van der Puije et al. 2000). There are few reports on age-related prevalence; however, those that exist report a gradual increase in prevalence with approximately $24 \%$ seroconversion per annum (Waldeland et al. 1977). In contrast, the study of Duncanson et al. (2001), using PCR diagnosis to estimate disease transmission to newborn lambs found high transmission rates $(61 \%)$. This study was based on a single lambing and could have been the result of an unusually high level of primary exposure to infection. Two important questions exist: are these levels of congenital transmission a consistent phenomenon across flocks or breeds and is congenital transmission a significant route of transmission in sheep? In this study we aim to address these questions by measuring rates of congenital transmission over time, between breeds and between farms.

\section{MATERIALS AND METHODS}

Commercial Suffolk-cross and pedigree Charollais sheep from a farm near Droitwich in Worcestershire were investigated over 5 subsequent lambings (March 1999-March 2001). Sampling was carried out over a period of 1-2 weeks during winter and spring lambings. Commercial sheep were lambed during both periods, whereas the Charollais flock were only lambed in winter. The two flocks were kept in separate housing and grazed in different areas allyear-round as required for the pedigree flock. This flock was maintained in house with replacement from home-grown stock rather than bought-in ewe lambs. Charollais sheep were also sampled on a second farm near Crewe in Cheshire for a single lambing period during the winter of 2001/02.

Collection of tissue samples was carried out as follows. For all samplings, a strict sterility regime was followed: tissues were removed using a fresh set of sterilized instruments for each tissue to prevent contamination across tissues and with external skin/ hair. Samples were kept in separate tubes and immediately frozen for storage. Instruments were thoroughly washed in Miltons solution and then sterilized using a portable steam sterilizer or by immersion in alcohol and flame treatment.

\section{Aborted lambs}

Lambs were dissected to reveal internal tissues (brain, heart, lung, liver, tongue) and tissues removed using the sterility protocol described above, taking care to use different, fresh, instruments for internal tissues following external dissection.

\section{Live lambs}

(a) During the Spring 1999 lambing, samples were taken from foetally-derived placental tissue or lamb cord immediately after birth as described previously (Duncanson et al. 2001). Sterile instruments were used throughout, care being taken to avoid crosscontamination and the sampler was present at all samplings. Samples were frozen immediately until DNA extraction could be undertaken. (b) All subsequent lambings (Winter 2000-Spring 2001; all Charollais samplings): umbilical cord tissue was taken aseptically immediately after birth using sterile instruments. The sampler was present at all samplings and the sample was not allowed to come into contact with other samples or with maternal tissue. Cord tissue was taken as close to the lamb as possible. Tissues were frozen immediately until DNA extraction could be performed.

All samples were transported to laboratories at Salford University for DNA extraction and PCR and these operations were conducted in such a way as to avoid any cross-contamination of samples. DNA was extracted from tissue samples as described previously (Duncanson et al. 2001; Terry et al. 2001) using a standard phenol-chloroform extraction process. For the detection of Toxoplasma gondii a nested polymerase chain reaction (PCR) was used to amplify the Surface Antigen Gene 1 (SAG1) (Savva et al. 1990), as described (Duncanson et al. 2001). Mammalian tubulin PCR was used as a positive PCR control for all samples as described previously (Terry et al. 2001. Products of amplification were identified by gel electrophoresis as described (Duncanson et al. 2001).

Reliability of PCR results was satisfied in a number of ways. Firstly, mice experimentally infected with reference isolates of Toxoplasma gondii (J. E. Smith, Leeds) showed SAG1 PCR amplification from internal tissues taken from infected mice while no amplification was achieved from uninfected mice. Secondly, the nested SAG1 PCR system was specific to Toxoplasma as amplification from DNA extracted from other related apicomplexans (Neospora, Sarcocystis, Hammondia) was not observed. Thirdly, the applicability of the procedure to field samples was judged by the successful SAG1 PCR amplification from sheep, fox, mouse, Apodemus, and human DNA spiked with low concentrations of Toxoplasma DNA but lack of amplification when they were spiked with any concentration of Neospora DNA. Finally, the reliability of the PCR analysis of lamb cord samples as indicators of PCR positivity of internal tissues, was judged by comparison in aborted lambs where both tissues could be sampled. In a sample of 
Table 1. Frequency of abortion and lamb losses in Suffolk cross and Charollais flocks

(Lambing losses in the 2 separate sheep flocks at the Droitwich Farm during the time period investigated. Differences in mean losses between commercial and Charollais sheep were found to be statistically significant. (Lamb losses: $\chi^{2}=27 \cdot 6$; D.F. $=1 ; P<0 \cdot 001 ;$ Pregnancy losses : $\chi^{2}=23 \cdot 9 ;$ D.F. $\left.=1 ; P<0 \cdot 001\right)$.)

\begin{tabular}{|c|c|c|c|c|c|c|c|}
\hline Flock & Lambing & $\begin{array}{l}\text { Spring } \\
1999\end{array}$ & $\begin{array}{l}\text { Winter } \\
2000\end{array}$ & $\begin{array}{l}\text { Spring } \\
2000\end{array}$ & $\begin{array}{l}\text { Winter } \\
2001\end{array}$ & $\begin{array}{l}\text { Spring } \\
2001\end{array}$ & Total \\
\hline Commercial & $\begin{array}{l}\text { No. aborted lambs } \\
\text { Total no. lambs } \\
\text { \% Lambs aborted } \\
\text { No. unsuccessful pregnancies } \\
\text { Total no. pregnancies } \\
\text { \% Pregnancies }\end{array}$ & $\begin{array}{l}61 \\
619 \\
9 \cdot 9 \% \\
39 \\
298 \\
13 \cdot 1 \%\end{array}$ & $\begin{array}{l}46 \\
505 \\
9 \cdot 1 \% \\
36 \\
296 \\
12 \cdot 2 \%\end{array}$ & $\begin{array}{l}26 \\
454 \\
5 \cdot 7 \% \\
20 \\
242 \\
8 \cdot 3 \%\end{array}$ & $\begin{array}{l}34 \\
386 \\
8 \cdot 8 \% \\
23 \\
240 \\
9 \cdot 6 \%\end{array}$ & $\begin{array}{l}30 \\
443 \\
6 \cdot 8 \% \\
20 \\
243 \\
8 \cdot 2 \%\end{array}$ & $\begin{array}{c}197 \\
2407 \\
8 \cdot 2 \% \\
138 \\
1319 \\
10 \cdot 5 \%\end{array}$ \\
\hline $\begin{array}{l}\text { Charollais } 1 \\
\text { (Sympatric) }\end{array}$ & $\begin{array}{l}\text { No. aborted lambs } \\
\text { Total no. lambs } \\
\text { \% Lambs aborted } \\
\text { No. unsuccessful pregnancies } \\
\text { Total no. pregnancies } \\
\% \text { Pregnancies }\end{array}$ & $\begin{array}{l}\text { N/A } \\
\text { N/A } \\
\text { N/A } \\
\text { N/A } \\
\text { N/A } \\
\text { N/A }\end{array}$ & $\begin{array}{l}21 \\
102 \\
20 \cdot 6 \% \\
14 \\
55 \\
25 \cdot 5 \%\end{array}$ & $\begin{array}{l}\text { N/A } \\
\text { N/A } \\
\text { N/A } \\
\text { N/A } \\
\text { N/A } \\
\text { N/A }\end{array}$ & $\begin{array}{l}20 \\
115 \\
17 \cdot 4 \% \\
16 \\
62 \\
25 \cdot 8 \%\end{array}$ & $\begin{array}{l}\text { N/A } \\
\text { N/A } \\
\text { N/A } \\
\text { N/A } \\
\text { N/A } \\
\text { N/A }\end{array}$ & $\begin{array}{c}41 \\
217 \\
18 \cdot 9 \% \\
30 \\
117 \\
25 \cdot 6 \%\end{array}$ \\
\hline $\begin{array}{l}\text { Charollais } 2 \\
\text { (Allopatric) }\end{array}$ & $\begin{array}{l}\text { No. aborted lambs } \\
\text { Total no. lambs } \\
\text { \% Lambs aborted } \\
\text { No. unsuccessful pregnancies } \\
\text { Total no. pregnancies } \\
\text { \% Pregnancies }\end{array}$ & $\begin{array}{l}\text { N/A } \\
\text { N/A } \\
\text { N/A } \\
\text { N/A } \\
\text { N/A } \\
\text { N/A }\end{array}$ & $\begin{array}{l}\text { N/A } \\
\text { N/A } \\
\text { N/A } \\
\text { N/A } \\
\text { N/A } \\
\text { N/A }\end{array}$ & $\begin{array}{l}\text { N/A } \\
\text { N/A } \\
\text { N/A } \\
\text { N/A } \\
\text { N/A } \\
\text { N/A }\end{array}$ & $\begin{array}{l}2 \\
44 \\
4 \cdot 5 \% \\
2 \\
24 \\
8 \cdot 3 \%\end{array}$ & $\begin{array}{l}\text { N/A } \\
\text { N/A } \\
\text { N/A } \\
\text { N/A } \\
\text { N/A } \\
\text { N/A }\end{array}$ & $\begin{array}{l}2 \\
44 \\
4 \cdot 5 \% \\
2 \\
24 \\
8 \cdot 3 \%\end{array}$ \\
\hline
\end{tabular}

42 aborted lambs, $36(86 \%)$ were either positive $(n=29)$ or negative $(n=7)$ for both lamb cord and the internal tissue while the remaining 6 were only positive in the internal tissues leading us to conclude that PCR amplification from lamb cord is a good indicator of the PCR status of internal tissue and, if anything, underestimates PCR positivity in internal lamb tissues. Good agreement was also found when comparing a range of internal tissues.

Statistical analyses of lambing results were carried out using the $\mathrm{Chi}^{2}$ test.

\section{RESULTS}

The aim of this study was to compare rates of Toxoplasma transmission and abortion over time, between breeds and between farms. Rates of congenital transmission were assessed in 5 sequential lambings over a period of 2 years in a flock of commercial sheep. In addition two Charollais sheep flocks were followed over the same period-first a sympatric and the second an allopatric population. In the commercial flocks between 8 and $13 \%$ of ewes aborted resulting in lamb losses of between $5 \cdot 7$ and $9 \cdot 9 \%$ (Table 1). In the sympatric Charollais flock these levels were higher with one in four ewes suffering abortion and lamb losses of 17-20\% (Table 1). In the allopatric population abortion occurred in $8 \cdot 3 \%$ of ewes with lamb losses of $4 \cdot 5 \%$ (Table 1 ).

Congenital transmission of Toxoplasma parasites was determined during a 2 -week sampling window in each lambing period of pregnancies (more sheep in Table 1) by SAG1 PCR amplification from internal tissues of dead lambs, lamb umbilical cord from live born lambs or occasionally placental tissue, which is foetally derived (see Materials and Methods section for details). These data show sustained high levels of congenital transmission over the study period (Table 2). Levels of congenital transmission remained high throughout the study with $47-78 \%$ of pregnancies affected and an overall mean for the 5 lambings of $69 \%$. Transmission rates in unsuccessful pregnancies (scored as those where one or more of the lambs was aborted, stillborn or died shortly after birth) were consistently high, with a mean of $91 \%$ lambs infected overall. In contrast, levels of congenital transmission in successful pregnancies had an overall mean of $65 \%$. There was a significant difference in the rate of maternal transmission between successful and unsuccessful pregnancies $\left(\chi^{2}=15 \cdot 8\right.$; D.F. $=1 ; P<0 \cdot 001)$.

To examine whether the high transmission rate was peculiar to the commercial sheep flock we conducted a parallel analysis of Charollais flocks on sympatric and allopatric farms (Table 3). Congenital transmission rates in the sympatric Charollais flock were found to be similar to the overall levels found in the commercial flock ( $60 \%$ of pregnancies). Again this level was significantly higher in the unsuccessful pregnancies $(96 \%)$ than in the successful ones $(43 \%)$ $\left(\chi^{2}=18 \cdot 7\right.$; D.F. $\left.=1 ; P<0 \cdot 001\right) . T$.gondii transmission rates were also high ( $41 \%$ of pregnancies) in a second Charollais flock on a separate geographically distant farm (Table 4). Infection rates here were not significantly higher in unsuccessful pregnancies (100\%) than in the successful ones $(36 \%)\left(\chi^{2}=3 \cdot 27\right.$; D.F. $=1$; $P=0 \cdot 07)$; however, lack of statistical significance may be due to the small sample size. 
Table 2. Toxoplasma infection in a Suffolk-cross flock (Droitwich)

(Congenital transmission of Toxoplasma gondii in a flock of commercial sheep over a period of 2 years. (Note: Spring 1999 data taken from Duncanson et al., 2001.) For cumulative data, differences in infection rates of lambs between successful and unsuccessful pregnancies were found to be significant $\left(\chi^{2}=15 \cdot 8 ;\right.$ D.F. $\left.=1 ; P<0 \cdot 001\right)$.)

\begin{tabular}{|c|c|c|c|c|}
\hline \multirow[b]{2}{*}{ Lambing } & \multirow[b]{2}{*}{ Data } & \multicolumn{2}{|c|}{ Outcome of pregnancy } & \multirow[b]{2}{*}{ Total } \\
\hline & & Successful & Unsuccessful & \\
\hline Spring 1999 & $\begin{array}{l}\text { No. of pregnancies } \\
\text { No. of PCR-positive pregnancies } \\
\text { Total }\end{array}$ & $\begin{array}{l}70 \\
37 \\
42 \%\end{array}$ & $\begin{array}{l}18 \\
17 \\
94 \%\end{array}$ & $\begin{array}{l}88 \\
54 \\
61 \%\end{array}$ \\
\hline Winter 2000 & $\begin{array}{l}\text { No. of pregnancies } \\
\text { No. of PCR-positive pregnancies } \\
\text { Total }\end{array}$ & $\begin{array}{l}57 \\
41 \\
72 \%\end{array}$ & $\begin{array}{l}15 \\
12 \\
80 \%\end{array}$ & $\begin{array}{l}72 \\
53 \\
74 \%\end{array}$ \\
\hline Spring 2000 & $\begin{array}{l}\text { No. of pregnancies } \\
\text { No. of PCR-positive pregnancies } \\
\text { Total }\end{array}$ & $\begin{array}{l}113 \\
83 \\
73 \%\end{array}$ & $\begin{array}{c}18 \\
18 \\
100 \%\end{array}$ & $\begin{array}{l}131 \\
101 \\
77 \%\end{array}$ \\
\hline Winter 2001 & $\begin{array}{l}\text { No. of pregnancies } \\
\text { No. of PCR-positive pregnancies } \\
\text { Total }\end{array}$ & $\begin{array}{l}44 \\
18 \\
41 \%\end{array}$ & $\begin{array}{c}7 \\
6 \\
86 \%\end{array}$ & $\begin{array}{l}51 \\
24 \\
47 \%\end{array}$ \\
\hline Spring 2001 & $\begin{array}{l}\text { No. of pregnancies } \\
\text { No. of PCR-positive pregnancies } \\
\text { Total }\end{array}$ & $\begin{array}{l}50 \\
39 \\
78 \%\end{array}$ & $\begin{array}{r}0 \\
0 \\
\text { N/A }\end{array}$ & $\begin{array}{l}50 \\
39 \\
78 \%\end{array}$ \\
\hline Cumulative & $\begin{array}{l}\text { No. of pregnancies } \\
\text { No. of PCR-positive pregnancies } \\
\text { Total }\end{array}$ & $\begin{array}{l}334 \\
218 \\
65 \%\end{array}$ & $\begin{array}{l}58 \\
53 \\
91 \%\end{array}$ & $\begin{array}{l}392 \\
271 \\
69 \%\end{array}$ \\
\hline
\end{tabular}

Table 3. Toxoplasma infection in Charollais flock 1 (sympatric population)

(Congenital transmission of Toxoplasma gondii in a flock of Charollais pedigree sheep over a period of 3 lambings (Winter- 2000, 2001 and 2002). Differences in lamb infection rates between successful and unsuccessful pregnancies were found to be significant $\left(\chi^{2}=18.7\right.$; D.F. $=1$; $P<0 \cdot 001)$.)

\begin{tabular}{llll}
\hline \hline & \multicolumn{2}{l}{ Outcome of pregnancy } & \\
\cline { 2 - 3 } Data & Successful & Unsuccessful & Total \\
\hline $\begin{array}{l}\text { No. of pregnancies } \\
\begin{array}{l}\text { No. of PCR-positive } \\
\text { pregnancies }\end{array}\end{array}$ & 49 & 24 & 73 \\
Total & $43 \%$ & 23 & 44 \\
\hline \hline
\end{tabular}

During later commercial lambings and for the two Charollais flocks, lamb cord was also sampled. This allowed rates of individual lamb infection to be determined, as well as maternal transmission. By analysis of this cumulative data (Table 5), it was shown that transmission of the parasite in these sheep flocks reaches $53 \cdot 7 \%$ of lambs. This rate of transmission was significantly higher in dead lambs (90\%) than in live ones $(46 \cdot 4 \%) \quad\left(\chi^{2}=43 \cdot 1 ; \quad\right.$ D.F. $=1$; $P<0 \cdot 001)$.

Given the high rates of congenital transmission occurring within these groups, we investigated possible patterns in the way the parasite was transmitted. No significant differences were seen with regard to lamb sex $\left(\chi^{2}=1.92 ;\right.$ D.F. $\left.=1 ; P=0 \cdot 17\right)$,
Table 4. Toxoplasma infection in Charollais flock 2 (allopatric population)

(Congenital transmission of Toxoplasma gondii over a single lambing period in the Cheshire farm flock of Charollais pedigree sheep. Differences in lamb infection rates between successful and unsuccessful pregnancies were not found to be significant using the chi squared test $\left(\chi^{2}=3 \cdot 27 ;\right.$ D.F. $\left.\left.=1 ; P=0 \cdot 07\right).\right)$

\begin{tabular}{lccc}
\hline \hline & \multicolumn{2}{l}{ Outcome of pregnancy } & \\
\cline { 2 - 3 } Data & Successful & Unsuccessful & Total \\
\hline $\begin{array}{l}\text { No. of pregnancies } \\
\begin{array}{l}\text { No. of PCR-positive } \\
\text { pregnancies }\end{array}\end{array}$ & 22 & 2 & 24 \\
Total & $36 \%$ & $100 \%$ & 10 \\
\hline \hline
\end{tabular}

although infection rates and mean losses were slightly higher in males. No significant differences was seen between the winter and spring lambings of the commercial flock $\left(\chi^{2}=1 \cdot 2\right.$; D.F. $\left.=1 ; P=0 \cdot 27\right)$.

Certain patterns did, however, emerge by grouping litter types together (i.e. singletons, twins, triplets) (Table 6). Firstly, there is a trend towards a higher level of transmission with an increased number of offspring, although this variation is not significant $\left(\chi^{2}=2 \cdot 49 ; \quad\right.$ D.F. $\left.=2 ; \quad P=0 \cdot 29\right)$. Secondly, as the number of offspring increases there is a significant increase in the risk of abortion $\left(\chi^{2}=16 \cdot 2\right.$; D.F. $=2$; $P<0 \cdot 001)$. This can be explained by the increased risk of mortality of infected lambs, which varies significantly with offspring number $\left(\chi^{2}=14 \cdot 6\right.$; 
Table 5. Cumulative individual lamb infection data (including all available data from the 3 flocks)

(Cumulative infection data in individual lambs. Differences in infection rates between live and dead lambs were found to be significant using the chi squared test $\left(\chi^{2}=43 \cdot 1 ;\right.$ D.F. $\left.=1 ; P<0 \cdot 001\right)$. $)$

\begin{tabular}{lllc}
\hline \hline Lamb Status & Alive & Dead & Total \\
\hline Total no. of lambs infected & 163 & 63 & 226 \\
Total no. of lambs & 351 & 70 & 421 \\
Total & $46 \cdot 4 \%$ & $90 \cdot 0 \%$ & $53 \cdot 7 \%$ \\
\hline \hline
\end{tabular}

Table 6. Lamb abortion and Toxoplasma infection rates by number of offspring (cumulative data for the 3 flocks)

\begin{tabular}{|c|c|c|c|c|}
\hline Litter type & $\begin{array}{l}\% \text { Aborted } \\
\text { lambs }\end{array}$ & $\begin{array}{l}\text { \% Lambs } \\
\text { infected }\end{array}$ & $\begin{array}{l}\text { Mortality in } \\
\text { infected lambs }\end{array}$ & $\begin{array}{l}\text { Mortality in } \\
\text { uninfected lambs }\end{array}$ \\
\hline Singletons & $\begin{array}{l}17 \cdot 9 \% \\
(12 / 67)\end{array}$ & $\begin{array}{l}50 \cdot 7 \% \\
(34 / 67)\end{array}$ & $\begin{array}{l}31 \cdot 3 \% \\
(11 / 34)\end{array}$ & $\begin{array}{l}3 \cdot 0 \% \\
(1 / 33)\end{array}$ \\
\hline Twins & $\begin{array}{l}12 \cdot 2 \% \\
(34 / 278)\end{array}$ & $\begin{array}{l}52 \cdot 2 \% \\
(145 / 278)\end{array}$ & $\begin{array}{l}20 \% \\
(29 / 145)\end{array}$ & $\begin{array}{l}3 \cdot 8 \% \\
(5 / 133)\end{array}$ \\
\hline Triplets & $\begin{array}{l}31 \cdot 9 \% \\
(23 / 72)\end{array}$ & $\begin{array}{l}62 \cdot 5 \% \\
(45 / 72)\end{array}$ & $\begin{array}{l}48 \cdot 9 \% \\
(22 / 45)\end{array}$ & $\begin{array}{l}3 \cdot 7 \% \\
(1 / 27)\end{array}$ \\
\hline Total* & $\begin{array}{l}16 \cdot 6 \% \\
(70 / 421)\end{array}$ & $\begin{array}{l}53 \cdot 7 \% \\
(226 / 421)\end{array}$ & $\begin{array}{l}31 \cdot 9 \% \\
(63 / 226)\end{array}$ & $\begin{array}{l}3 \cdot 6 \% \\
(7 / 195)\end{array}$ \\
\hline
\end{tabular}

D.F. $=2 ; P<0.001)$. There is no significant increase in uninfected offspring (Fisher's exact test; $P>0 \cdot 05$ ).

\section{ISCUSSION}

At the outset of study we raised the question of whether the elevated level of vertical transmission reported in sheep (Duncanson et al. 2001) was caused by unusual circumstances such as a high level of primary infection. Abortion storms, presumed to be associated with a wave of primary infection with Toxoplasma, have been known to occur (Hartley \& Marshall, 1957) and it is suggested that these outbreaks can be attributed to contact between the flock and infected cats during gestation. By using PCR positivity of the Toxoplasma SAG 1 gene as a measure of infection with Toxoplasma, our data clearly show that vertical transmission occurs in $60-70 \%$ of all pregnancies and that this figure remains consistent through time, and with season, breed and geographical area. The result of this is that approximately $46 \cdot 4 \%$ of live lambs are born infected. This figure is much higher than the $7 \cdot 6-16 \cdot 2 \%$ predicted from serological assessment (Skjerve et al.
1998; Van der Puije et al. 2000). These differences in the sensitivity of PCR and serological assay are known to exist. PCR detects the presence of parasite DNA in tissue samples while serological methods measure exposure to the parasite. In a comparative study of PCR with mouse inoculation and serological methods it was found that PCR was at least as sensitive as mouse inoculation and better than some serological methods as a diagnostic tool for ovine toxoplasmosis (Owen, Clarkson \& Trees, 1997). Several authors report that PCR-based assays are more sensitive in detection of the parasite than serology (Owen \& Trees, 1998; Hafid et al. 2001) and in one study it was reported to be more accurate than the modified agglutination test (MAT) especially in the diagnosis of vertical transmission (Owen \& Trees, 1998). In mice, it has been suggested that this latter phenomenon may be explained by compromised antibody responsiveness of young mice born to chronically infected dams (Suzuki \& Kobayashi, 1990). There clearly remains a discrepancy between levels of serological and PCR positivity in newborn lambs in the literature, and further investigation is needed to understand the immunological interactions 
occurring at this stage. We do not know the consequences of infection in live born lambs, whether they go on to develop systemic disease and chronic parasitaemia or whether parasite infection fails to establish. However, this early exposure to the parasite could compromise the development of anti-parasite immunity enhancing the likelihood that serial vertical transmission could occur. Vertical transmission is consistent with the data presented in this study.

Vertical transmission of $T$. gondii over one generation has been demonstrated unequivocally in experimentally infected mice (Owen \& Trees, 1998). In the closely related parasite Neospora caninum, vertical transmission is known to occur in several host animals including mice (Cole et al. 1995), dogs (Barber \& Trees, 1998), foxes (Schares et al. 2001) and in cattle, where serial vertical transmission is very efficient (Davison, Otter \& Trees, 1999) and is often associated with foetal pathology (Bjorkman et al. 1996).

The overall rate of $53 \cdot 7 \%$ vertical transmission for Toxoplasma in sheep reported in this study may not be sufficient to sustain parasite infection within sheep populations and it is likely that the parasite has the capacity for both vertical and horizontal transmission and the use of these routes might vary according to host, parasite strain and prevailing environmental conditions. In support of a role for vertical transmission, Terry et al. (2001), carrying out an initial genotyping study on this farm, found that Toxoplasma isolates taken from this flock had identical MGE genotypes.

We found a strong relationship between infection and abortion with $90 \%$ of aborted animals being Toxoplasma positive compared to $46 \cdot 4 \%$ of live-born individuals. Abortion rates were higher in Charollais raising the possibility that pathogenesis varies with host breed. In addition to breed, other factors may also contribute to abortion; one of the most interesting of these is the positive relationship between the number of offspring and rates of infection and abortion. In humans, it has been proposed that reactivation of Toxoplasma infection and consequent abortion might result from pregnancy-induced stress and that that would be more severe in triplets than in twins and singletons (Avelino \& Campos, 2002). If this were also the case in sheep, our data would be consistent with such a concept.

The importance of vertical transmission of Toxoplasma requires closer evaluation. In particular, a crucial question which needs to be addressed, is whether this transmission is due to primary infection during pregnancy or reactivation from chronic infection. If the latter is the case then animal husbandry, control methods and management techniques may need to be re-evaluated; vaccine strategies may need to focus on preventing transmission rather than reducing levels of foetal abortion. Further work is necessary to address these important questions.
Future epidemiological studies will be needed to determine whether vertical transmission of Toxoplasma is a common feature in herbivores and if so whether it might contribute to the clonal 'asexual' expansion and parasite population structure seen across Europe and North America (Su et al. 2003).

We would like to thank the University of Salford, The Perry Foundation, The Wellcome Trust and the Yorkshire Agricultural Society for funding. We gratefully acknowledge the contribution of Allan Maiden, Sue Davies and their families to this research. We would also like to thank Dr Rupert Quinell for helpful input on statistical analysis.

\section{REFERENCES}

AVELino, M. M. \& CAMPos, Jr. D. (2002). Pregnancy as a risk factor for acute toxoplasmosis seroconversion. European Fournal of Obstetrics, Gynaecology and Reproductive Biology 4417, 1-6.

BARBER, J. S. \& TREES, A. J. (1998). Naturally occurring vertical transmission of Neospora caninum in dogs. International fournal for Parasitology 28, 57-64. Beverley, J. K. A. (1959). Congenital transmission of Toxoplasmosis through successive generations of mice. Nature, London 183, 1348-1349.

Beverley, J. K. A. \& WATSON, W. A. (1971). Prevention of experimental and of naturally occurring ovine abortion due to toxoplasmosis. Veterinary Record 88, 39-41.

BJORKMAN, C., JOHANSSON, O., STENLUND, S., HOLMDAHL, O. J. \& UGGLA, A. (1996). Neospora species infection in a herd of dairy cattle. Fournal of the American Veterinary Medicine Association 208, 1441-1444.

BLEWETT, D. A. (1983). The epidemiology of ovine toxoplasmosis. I. The interpretation of data for the prevalence of antibody in sheep and other host species. British Veterinary fournal 139, 537-545.

BUXTON, D. (1990). Ovine toxoplasmosis: a review. Fournal of the Royal Society of Medicine 83, 509-511.

COLE, R. A., LiNDSAY, D. S., BLAGBURN, B. L. \& DUBEY, J. P. (1995). Vertical transmission of Neospora caninum in mice. Fournal of Parasitology 81, 730-732.

DAVISON, H. C., OTTER, A. \& TREES, A. J. (1999). Estimation of vertical and horizontal transmission parameters in Neospora caninum infections in dairy cattle. International Fournal for Parasitology 29, 1683-1689.

Dubey, J. P. \& BEATTIE, C. P. (1988). Toxoplasmosis of Animal and Man. CRC Press, Boca Raton, Fl, USA.

DUBEY, J. P. \& SHEN, S. K. (1991). Rat model of congenital toxoplasmosis. Infection and Immunity 59, 3301-3302.

DUBEY, J. P., SHEN, S. K., KWOK, O. C. H. \& THULLIEZ, P. (1997). Toxoplasmosis in rats (Rattus norvegicus): congenital transmission to first and second generation offspring and isolation of Toxoplasma gondii from seronegative rats. Parasitology 115, 9-14.

DUNCANSON, P., TERRY, R. S., SMITH, J.E. \& HIDE, G. (2001). High levels of congenital transmission of Toxoplasma gondii in a commercial sheep flock. International Fournal for Parasitology 31, 1699-1703.

HAFID, J., FLORI, P., RABERIN, H. \& TRAN MANH SUNG, R. (2001). Comparison of PCR, capture ELISA and immunoblotting for detection of Toxoplasma gondii in 
infected mice. Fournal of Medical Microbiology 50, 1100-1104.

HARTLEy, W. J. \& MARShall, s. C. (1957). Toxoplasmosis as a cause of ovine perinatal mortality. New Zealand Veterinary fournal 5, 119-124.

HUTCHisON, W. M. (1965). Experimental transmission of Toxoplasma gondii. Nature, London 206, 961-962.

JOHNSON, A. M. (1997). Speculation on possible life cycles for the clonal lineages in the genus Toxoplasma. Parasitology Today 13, 393-397.

LEgUia, G. \& HERBERT, I. v. (1979). The prevalence of Sarcocytis spp. in dogs, foxes and sheep and Toxoplasma gondii in sheep and the use of the indirect

haemagglutination reaction in serodiagnosis. Research in Veterinary Science 27, 390-391.

MARSHALL, P. A., HUGHES, J. M., WILLIAMS, R. H., SMITH, J. E., MURPHY, R. G. \& HIDE, G. (2004). Detection of high levels of congenital transmission of Toxoplasma gondii in natural populations of Mus domesticus. Parasitology 128, $1-4$.

OWEN, M. R. \& TREES, A. J. (1998). Vertical transmission of Toxoplasma gondii from chronically infected house (Mus musculus) and field (Apodemus sylvaticus) mice determined by polymerase chain reaction. Parasitology 116, 299-304.

owen, M. R., Clarkson, M. J. \& Trees, A. J. (1997). Diagnosis of ovine Toxoplasma abortion by polymerase chain reaction. Veterinary Record 142, 445-448.

RoEver-Bonnet, H. DE (1969). Congenital Toxoplasma infections in mice and hamsters infected with avirulent and virulent strains. Tropical and Geographical Medicine 21, 443-450.

SAC. VETERINARY SCIENCE DIVISION. (1999). Sheep abortion figures analysed as the 1999 lambing season ends in Scotland. Veterinary Record 145, 240-242.

SAMAD, M. A. \& ClaRkson, M. J. (1994). Seroconversion to natural Toxoplasma gondii infection during reproductive cycle and its effect on reproduction on sheep. Bangladesh Veterinary fournal 28, 1-6.
SAVVA, D., MORRIS, J. C., JOHNSON, J. D. \& HOLLIMAN, R. E. (1990). Polymerase chain reaction for the detection of Toxoplasma gondii. Fournal of Medical Microbiology 32, $25-31$.

SCHARES, G., WENZEL, U., MULleR, T. \& CONRATHS, F. J. (2001). Serological evidence for naturally occurring transmission of Neospora caninum among foxes (Vulpes vulpes). International Fournal for Parasitology 31, 418-423.

SKJERVE, E., WALDELAND, H., NESBakKen, T. \& KaPPERUd, G. (1998). Risk factors for the presence of antibodies to Toxoplasma gondii in Norwegian slaughter lambs. Preventative Veterinary Medicine 35, 219-227.

SU, C., EVANS, D., COLE, R. H., KISSINGER, J. C., AJIOKA, J. W. \& SIBLEY, L. D. (2003). Recent expansion of Toxoplasma through oral transmission. Science 299, 414-416.

SUZUKI, Y. \& KOBAYASHI, A. (1990). Induction of tolerance of Toxoplasma gondii in newborn mice by maternal antibody. Parasitology Research 76, 424-427.

TENTER, A. M., HeCKeroth, A. R. \& Weiss, L. M. (2000). Toxoplasma gondii: from animals to humans. International Fournal for Parasitology 30, 1217-1258.

TERry, R. S., SMITH, J. E., DUNCANSON, P. \& HIDE, G. (2001). MGE-PCR: a novel approach to the analysis of Toxoplasma gondii strain differentiation using mobile genetic elements. International Fournal for Parasitology 31, 155-161.

VAN DER PUIJE, W. N., BOSOMPEM, K. M., CANACOO, E. A., WASTLING, J. M. \& AKANMORI, B. D. (2000). The prevalence of anti-Toxoplasma gondii antibodies in Ghanaian sheep and goats. Acta Tropica 76, 21-26.

WALDELAND, H. (1977). Toxoplasmosis in sheep - influence of various factors on antibody contents. Acta veterinaria scandinavica 18, 237-247.

ZENNER, L., DARCY, F., CESBRON-DELAUW, M. F. \& CAPRON, A. (1993). Rat model of congenital toxoplasmosis- rate of transmission of 3 Toxoplasma gondii strains to foetuses and protective effect of a chronic infection. Infection and Immunity 61, 360-363. 